\title{
Renal Pelvis and Ureter Cancer pT1 TNM
} Finding v8

National Cancer Institute

\section{Source}

National Cancer Institute. Renal Pelvis and Ureter Cancer pT1 TNM Finding v8. NCI

Thesaurus. Code C140344.

Renal pelvis and ureter cancer in which the tumor invades subepithelial connective tissue.

(from AJCC 8th Ed.) 